\title{
The elephant and the neutrino
}

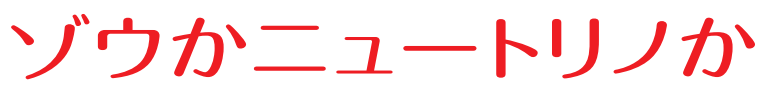

Kullugudi Jayaraman

Nature Vol. 461(459)/24 September 2009

インドでは、現在、地下ニュートリノ観測施 設「インドニュートリノ観測所 (INO)」の 建設予定地をめぐって、問題が起こってい る。建設を推進する物理学者と自然保護を 訴え反対する人たちが対立しているのだ。

この施設は、ニュートリノという捕らえに くい粒子を研究するために建設される。建 設費は 1 億 6000 万ドル（約 150 億円； 1 ドル $=91$ 円換算）で、2012 年までに 完成する予定だった。しかし建設予定地は、 バンガロールの南 250 キロメートルにあ るニルギリ生物圏保護区内のシンガーラと いう、ゾウとトラの重要な生息地にある。 そのため、建設場所の是非をめぐって激し い論争が起こり、建設計画は頓挫している。

この観測施設をシンガーラに建設する認 可申請は、2006 年に提出された。プロジェ クトのスポークスマンである夕夕基礎研究所 (ムンバイ) の物理学者 Naba Mondal は、 「現在まで、政府からの回答はありません」 と話す。予定地のある夕ミルナドゥ州の森 林管理責任者である A. S. Balanathan は、 「わかっていることは、まだその件は未処 理だということだけです」と話す。

今年 8 月、ノーベル賞受賞者のシェル ドン・グラショウボストン大学 (米国) 教 授、小柴昌俊東京大学名誉教授を含む 11 人の著名な物理学者が、シン首相に書 簡を送り、計画の推進を要請した。彼らは、 「INO はインドにビッグサイエンスをもた らし、最先端科学の重要な担い手としてイ ンドの役割を高めることになる」と提言し た。一方、インドの著名な環境保護専門 家らは、計画に対する懸念を表明し、観 測所をほかの場所に設置するよう求め、 署名活動を行っている。
ニルギリ生物圏保護区には、5500 平 方キロメートルを超えるひと続きの森林 と、6つの自然保護区域がある。建設予 定地は、そのうちのある自然保護区域か ら7キロメートルしか離れていない。計 画によると、ニルギリ丘陵の下にトンネル を2キロメートル掘り、その先端に長さ 120 メートルの「巨大洞窟」を建造する。 巨大洞窟には、ニュートリノがまれに物質 と相互作用するときに生まれるミュー粒子 を検出するため、磁化鉄などでできたカ口 リメーターが設置される。建設計画が論 争の的となっているのは、トンネル掘削と 人口増加が壊れやすい生態系に及ぼす影 響について、双方の意見が食い違ってい るからだ。保護区への影響を懸念するイン ドの自然保護団体が組織した「NBR 同盟」 は、「建設が行われれば、63 万トンのが れきと 14 万 7000 トンの建設資材を運ぶ ため、のべ約 15 万 6000 台のトラックが 森林地带 35 キロメートルとトラの保護区 2 か所を通過することになるでしょう」と 話す。これは動物たちの移動ルートを 46 万 8000 時間にわたって妨害することにな る、とNBR 同盟は見積もっている。

インドのゾウの生息地を調査したこと があるオーストラリアの環境問題専門家 John Seed は、「インドでここ以上に野生 生物に損害を与える可能性が高い場所は、 ほかにないでしょう。ニルギリ保護区は、 アジアゾウの世界最大の集団の生息地で あると同時に、インドで最も重要なトラの 生息地の 1 つでもあるからです」と話す。

Mondal は、建設で生じるがれきの量 に関するNBR 同盟の見積もりを疑問視し、 「我々の計画では、トラックの通行を昼間

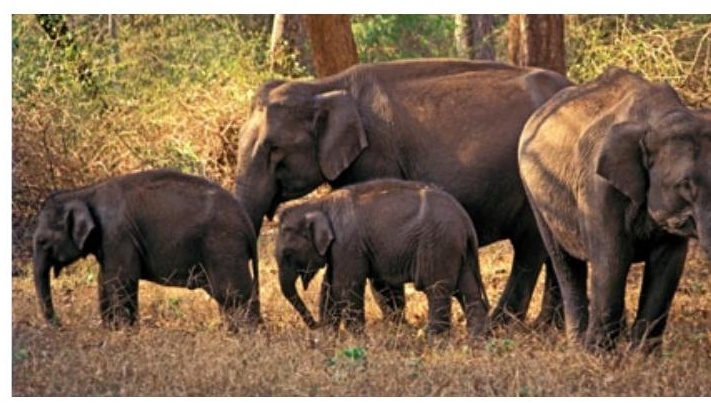

だけとし、回数も制限します」と話す。しかし、 ポンディシェリ大学 (インド) の環境問題専 門家で熱帯生物学・保護協会 (米国ワシン トンDC)会長の Priya Davidar は、「プロジェ クトが政府に提出した環境影響評価には、 重大な欠陥があります」と話す。同協会は、 インド政府に建設を許可せず、代替建設地 を探すように促す決議案を採択した。

Davidar は「この計画ではたった 2 か 所の候補地から予定地を選んだのです」 と批判し、「1965 年にニュートリノ検出実 験に使われた、隣のカルナータカ州のコ ラール金鉱山の方が適していたでしょう」 と主張する。しかし Mondal は、「コラー ル金鉱山は現在閉鎖され、内部は水が充 満しており、重い資材を降ろすのには適し ていません。我々はインド地質調査所とと もに、いろいろな場所を検討し、安全性、 周辺の地震活動、年間を通じてのアクセ スなどから、シンガーラをINO の建設に 最適な場所と判断したのです」と語る。

今後の現地調査いかんによって、建設許 可の申請が却下されたなら、研究チームは 別の場所を探さなければならないだろう。 (新庄直樹 訳)

註：11月20日、インドのラメシュ環境森林相は、シン ガーラへの建設を許可せず、代替地の検討を提言した。 